\title{
CHILDREN AND ADOLESCENTS WITH CEREBRAL PALSY: ANALYSIS OF CARE LONGETUDINALITY
}

\author{
Keite Helen dos Santos ${ }^{1}$, Dalvani Marques², Ândrea Cardoso de Souza $a^{3}$
}

${ }^{1}$ Nurse. Resident Nurse in the Residência Multiprofissional da Faculdade de Ciências Médicas, Universidade Estadual de Campinas. Campinas, São Paulo, Brazil. E-mail: keiteenf@yahoo.com.br

${ }^{2}$ Ph.D. in Nursing. Professor, Nursing Faculty of Universidade Estadual de Campinas. Campinas, São Paulo, Brazil. E-mail: marquesdal@ yahoo.com.br

${ }^{3}$ Ph.D. in Nursing. Professor, Escola de Enfermagem Aurora de Afonso Costa, Universidade Federal Fluminense. Niterói, Rio de Janeiro, Brazil. E-mail: andriacz@ig.com.br

\section{ABSTRACT}

Objective: to analyze the longitudinality of care perceived by caregivers of children and adolescents with cerebral palsy.

Method: qualitative and descriptive investigation, performed with 27 caregivers, through interviews, analyzed using the thematic analysis technique based on Care Longitudinality.

Results: the need of extreme dedication of the caregivers to the care of their children and adolescents with cerebral palsy was highlighted, with the need to abandon their free time, daily activities and the abandonment of the professional activities. As the child grows, the complexity of daily activities increases and, consequently, the pronouncement of the difficulties experienced by the families. The statements demonstrate the absence / lack of formal responses from the State to the needs of care of the studied population, a condition that helps to naturalize this support as family responsibility. They indicate the inexistence of articulated care network for this population, implying the discontinuity of care among services which impacts on the quality of life of children and their families.

Conclusion: the lack of articulation between services implies discontinuity of health care, deteriorating the quality of life of children and their families and negatively impacting on the health outcomes of the health care system, since there is an inefficient use of resources. The establishment of care and the way it given is an inseparable component of care services management responsible for guaranteeing equity and integrality of the research.

DESCRIPTORS: Health care. Cerebral palsy. Health services. Primary health care. Collective health.

\section{CRIANÇAS E ADOLESCENTES COM PARALISIA CEREBRAL: ANÁLISE SOBRE LONGITUDINALIDADE DO CUIDADO}

\section{RESUMO}

Objetivo: analisar a longitudinalidade do cuidado percebida pelos cuidadores de crianças e adolescentes com paralisia cerebral. Método: investigação qualitativa, descritiva, realizada com 27 cuidadores, por meio de entrevistas, analisadas com a técnica de análise temática, com base na Longitudinalidade do Cuidado.

Resultados: apontaram a necessidade de extrema dedicação dos cuidadores aos cuidados de suas crianças e adolescentes com paralisia cerebral, sendo necessária a abdicação ao tempo livre, às atividades diárias e o abandono das atividades profissionais. À medida que a criança cresce aumenta a complexidade das atividades diárias e, consequentemente, o pronunciamento das dificuldades vivenciadas pelas famílias. Os discursos demonstram a ausência/deficiência das respostas formais do Estado às necessidades integrais de cuidado à população estudada, condição que contribui para naturalizar esse apoio como responsabilidade familiar. Indicam a inexistência de uma rede desarticulada de cuidado para esta população, implicando a descontinuidade de atenção entre os serviços e impactando na qualidade de vida das crianças e suas famílias.

Conclusão: a falta de articulação entre os serviços implica descontinuidade da atenção à saúde, deteriorando a qualidade de vida das crianças e de suas famílias e impactando negativamente nos resultados sanitários do sistema de atenção à saúde, uma vez que há a utilização ineficiente dos recursos. O estabelecimento de fluxos de cuidado é um componente indissociável da gestão dos serviços de atenção, responsável pela garantia da equidade e integralidade aos sujeitos investigados.

DESCRITORES: Assistência à saúde. Paralisia cerebral. Serviços de saúde. Atenção primária à saúde. Saúde pública. 


\section{NIÑOS Y ADOLESCENTES CON PARÁLISIS CEREBRAL: ANÁLISIS SOBRE LONGITUDINAL DEL CUIDADO}

\section{RESUMEN}

Objetivo: analizar la longitudinal del cuidado percibida por los cuidadores de niños y adolescentes con parálisis cerebral.

Método: investigación cualitativa, descriptiva, realizada con 27 cuidadores, por medio de entrevistas, analizadas con la técnica de análisis temática con base en la longitudinal del cuidado.

Resultados: apuntaron la necesidad de extrema dedicación de los cuidadores a los cuidados de sus niños y adolescentes con parálisis cerebral, siendo necesaria la abdicación al tiempo libre, a las actividades diarias y el abandono de las actividades profesionales. A medida que el niño crece aumenta la complejidad de las actividades diarias y consecuentemente, el pronunciamiento de las dificultades vividas por las familias. Los discursos demostraron la ausencia/deficiencia vividas por las familias. Los discursos demostraron la ausencia/deficiencia de las respuestas formales del Estado a las necesidades integrales del cuidado a la población estudiada, condición que contribuye a naturalizar ese apoyo como responsabilidad familiar. Indican la inexistencia de una red desarticulada de cuidado para esta población, implicando la discontinuidad de atención entre los servicios e impactando en la calidad de vida de los niños y sus familias.

Conclusión: la falta de articulación entre los servicios implica discontinuidad de la atención a la salud, deteriorando la calidad de vida de los niños y de sus familias e impactando negativamente en los resultados sanitarios del sistema de atención a la salud, una vez que hay utilización ineficiente de los recursos. El establecimiento de flujos de cuidado es un componente indisociable de la gestión de los servicios de atención, responsable por la garantía de equidad e integralidad a los sujetos investigados.

DESCRIPTORES: Asistencia en salud. Parálisis cerebral. Servicios de salud. Atención primaria de salud. Salud pública.

\section{INTRODUCTION}

Chronic illness is a condition that lasts for a long time and causes limitations and incapacity in a progressive way, impacting the patient, the family, the society and interferes with public policies because it represents a complex clinical condition that generates high costs. ${ }^{1}$ Cerebral palsy is classified as a physical disability in children and is strongly associated with public health issues and is characterized by the presence of multiple disabilities and different levels of dependency. ${ }^{2-3}$ Despite advances in medicine, the incidence of cerebral palsy is reported in approximately two per 1,000 live births, and is higher in underdeveloped countries with seven cases per 1,000 births. ${ }^{13}$ Although the risk of occurrence increases with preterm birth, it is not uncommon for infants to mature, with an incidence of 1.1 cases per 1,000 Live births, even at full term pregnancies. ${ }^{2}$

The health care of this population is guided by a logic of offering services that reduce mortality rates. However, caring for these children demands a complex and long-term actions, since most have multiple chronic diseases and require different care according to their development. Considering the characteristics of chronicity, there is no regression of the condition, the most appropriate action is the slowing of its progression and the search for quality of life. Thus, primary care is the most appropriate attention for the implementation of care for this population. ${ }^{4}$

Primary health care (PHC) is characterized by actions guided by the expanded concept of health, focusing on the production of autonomy, coping with vulnerabilities, valuing cultural differences, and humanized and integral care. ${ }^{5}$ There are four characteristics for PHC: First contact, longitudinality, care coverage and coordination. ${ }^{6}$ In this study we will discuss the importance of longitudinality for a more effective and affective care.

In the context of $\mathrm{PHC}$, longitudinality ${ }^{6}$ refers to a lasting link between users and health professionals. It is the guarantee of ccontinuity of care over time, regardless of the existence of problems or illnesses, a condition in which the service becomes the reference for the clientele. According to this principle, people can rely on health services as a source of attention, if needed, and can participate in various activities, in addition to the treatment of diseases, such as those related to health promotion, for example.

Despite being considered the organizing center in the health system of our country, PHC presents great fragilities in relation to the coordination of care, the guarantee of actions based on longitudinality and the operationalization of care that respects the integrality, equity and universality. The lack of an integrated care network is considered a major obstacle in the access to different services for the network of children and adolescents with cerebral palsy. In this perspective, the family plays a central role in the continuity of care, assuming the responsibility of the coordination, articulation and the responsibility of primary care services. ${ }^{7}$

The answer to this problem is structured in the understanding that the attention to the specifics of this population must be guided by micropolitical management, oriented by actions of integrality and attending to their needs. Their coordination depends on actions in a network and not just the family, joining knowledge and practices together in order to establish an adequate flow of care which offers support to children and their caregivers. Based on the above statement, the objective of this article is 
to analyze the longitudinality of care based on the perception of caregivers of children and adolescents with cerebral palsy.

\section{METHOD}

A descriptive study with a qualitative approach, performed in a nongovernmental service for deaf and blind children and adolescents with multiple disabilities, located in Campinas-SP. This service is a reference in the care of disabled people for the six municipalities that make up this metropolitan region.

Data were collected through semi-structured interviews, between July and August 2015, with the caregivers of children and adolescents diagnosed with cerebral palsy. The inclusion criterion was to be the caregiver of a child or adolescent with cerebral palsy. Exclusion criteria were considered to be the parent or caregiver of people with cerebral palsy outside the age range of 0 to 18 years of age.

The data collection instrument consisted of a semi-structured script divided into two sections. The first one was about the identification and sociodemographic characterization of caregivers and their families; and the second, composed of open questions, whose purpose was to approach the central theme of this study. Thus, caregivers were questioned about the type of relationship they had with the child or adolescent and about the health services that were established after the birth of the child with cerebral palsy.

The statements obtained during the meetings were recorded, transcribed and analyzed using the content analysis method of thematic analysis, ${ }^{8}$ contributing to the identification of the core meanings, as well as the presence or frequency of significant factors for the object studied, allowing the grouping of ideas, words, expressions or elements around concepts, constituting the categories.

The analysis of the categories was based on the prism of the longitudinality of care, considered a central characteristic of Primary Health Care, which monitoring of the individual over time is performed by the health team in its entirety, i.e. e throughout the process of illness or the development of preventive actions. ${ }^{6}$

The analysis of the statements with the longitudinality of the care in consideration, facilitated the identification of the application (or absence) of this attribute during the monitoring of children with cerebral palsy and their families in the health care network in the city of Campinas-SP.
The research obeyed the ethical and legal precepts regulated by Resolution No. 466/12, of the National Health Council, and was approved by the Research Ethics Committee of the Universidade Estadual Campinas, under the opinion No. 1027960/2015, CAAE: 42446015.0. 0000.5404.

\section{RESULTS}

The sample was obtained by the process of saturation in the interviews, this study composed of reports from 27 caregivers (one father, four grandmothers, two sisters and 20 mothers) of children with cerebral palsy, attended in a referenced nongovernmental organization for the care of deaf and blind children and adolescents and multiple disabilities, in Campinas, SP. This institution is responsible for the care of approximately 34 children and their families, and often the only caring for children over 5 years of age.

The age range of children and adolescents who composed this study ranged from 2 to 16 years (eight were in the $0-5$ age group, 10 were in the 6 to 10 age group, and 9 were between 11 and 16 years of age). Self-declaration of race/ethnicity consisted of17 identifying as white, eight as pardo/brown and two as black individuals. The ages of the caregiver ranged from 18 to 65 years (three were between 18 and 25 years of age, seven were between 26 and 33 years of age, seven were between 34 and 41 years of age, six were between 42 and 49 years of age, two were between 50 and 57 years of age and two were between 58 and 65 years of age), with predominance of females ( 26 females and one male).

In relation to declared family income, 19 caregivers reported between $\mathrm{R} \$ 788$ amd $\mathrm{R} \$ 236$, seven individuals reported between $\mathrm{R} \$ 3152$ and $\mathrm{R} \$ 4728$ and one referred income above R $\$ 4728$. Of the 27 caregivers, seven worked, 20 stopped working due to taking care of the child or adolescent, and one did not work.

The studied profile shows the predominance of a population dependent on the Brazilian Unified Health System (SUS): 19 caregivers reported exclusive family use of SUS services, eight caregivers reported that children or adolescents under their responsibility, used other non-SUS health services.

The statements of the family caregivers of the children and adolescents from the studied institution made it possible to understand the path traveled by these families in search of qualified care and assistance for their children.

Three categories emerged which will be detailed based on interviews with the caregivers: Fam- 
ily rearrangements: life projects and coping; Family care in situations of chronic illness; In search of the health care network: the point of view of caregivers of children and adolescents with cerebral palsy.

\section{Family rearrangements: life projects and coping}

The following is the caregivers' description of the repercussions, the elaboration of the confrontations and the attempt to hide the prognosis faced with the diagnoses of their children: I was desperate, I was very ... very angry because she did everything to be a normal child (FIII); My whole life has changed. First I learned a lot, I learned to deal with these situations, learned to be patient, learned to be calmer. To give value to human beings, to stop being materialistic... (FVI); I stopped living my life to take care of her (FVII).

The statements show that most caregivers feel (or feel) fearful because of the need to care for the child or adolescent, noting that they do not feel prepared to face the situations associated with the clinical conditions of their children, since the health needs were (or are) quite complex ,causing fear and insecurity. I'm just scared... because she has a swallowing problem, she chokes and everything... then I'm a little afraid she has some complications, that sometimes she chokes on some things, drinking some things, liquid, sometimes she chokes, something gets stuck, even when I am giving medicine, sometimes ... I just get (FIX).

In this perspective, family routines and plans have changed, as have the priorities and desires of those responsible for these individuals. He's close to walking ... it could be a month from now, a year from now, two years from now ... He's going to walk. He will have his life (FVIII); If God gave me this boy it is because I deserve it and I will take care of him with the greatest affection and if I have to stay up all night with him I will do it, it is my passion (FI); Oh, I hope that he can become more independent, ifhe's able. But I know it won't be easy. I hope he can develop and be able to do some things on his own, be able to walk, be able to feed himself ... (FV). Oh, she's doing enough physical therapy for her to make progress, she gets smarter, meets more people, comes and walks, and talks... (FVI).

The father participates in this care in a more inexpressive way. However, there is an attempt to "hide" the limitations of the child from society, and the social aspect, the shame, is more impactful than the difficulty with the child itself. It's like, you try ... it's a scare ... you try to hide from everyone that ... until you know, because I did not know either (FXI).

Caregivers' routines are often summarized in the treatment of children, a condition reported as a key factor in maximizing their growth, development and independence. Now it's all practically for him. All the chores, [...] Everything is harder for me to do now, what I did before, the house, now I always do things first for him, then in my spare time I do what I can (FV) . [...] ah ... it changed everything, I thought about working ... nowadays I can't work (FVI).

\section{Family care in chronic illness}

In the development of care for the child or adolescent with cerebral palsy, caregivers describe the difficulties experienced during this process. No one could explain. For example I wanted to know how to feed him, without having the gastro [gastrostomy], because he sucked, but sometimes he choked on it (FII); They do not ask me what I was in doubt about and only responded sometimes. If I forget to ask they do not even think about what I might or might not know (FV); [...] To get a device that she has, which is the button, I had to go to court to ask for the money to buy the expensive milk that she has to have, and I went to court to get a medicine that she has to have and I'm trying to get in the justice again to get the material she needs, because now there is a shortage and it doesn't come very often (FVI).

We can observe that the statement of parents, mothers and grandmothers of children and adolescents with cerebral palsy are permeated by a subjectivity that considers the parental ties as determinants in the obligation to care. For me to give the fluids, I let it dry very well, then I put the little eye to dry quickly. I learned how to do it, I do it (FI). I have doubts every day ... about how to clean him, how to feed him... (FXXVII). I did not know how to take care of the stomach tube, the gastro [gastrostomy], I did not know how to position her I asked for a lot of help for many places and no one supported me in anything, not even the hospital. I even went to the doctors and nurses, but no one paid any attention to me. But now I already know everything (FXXII).

When questioned about the future care of these children and adolescents it is possible to perceive that there is a concern to find "substitutes" who will be responsible for the continuity of the activities carried out by the parents. I'm just afraid that when I die, who's going to stay with him? People do not care for his health now, without me around what will they do? Leave him in bed without food until he dies? (FII); I am afraid, it's an uncertain future, of him being kind of innocent and the others taking advantage of him. We had another child, thinking of him. We are educating his brother to take care of him, I am afraid of him being harassed, mistreated. [cries] (FXIV); [...] Oh ... I cannot imagine ... I cannot imagine her future, no, I cannot 
imagine because it it impossible to imagine (FIX); Being dependent, always taking care of him, he will akways be dependent, the doctors said no, but he will be, yes (FXI).

\section{In search of the health care network: the perception of caregivers about children and adolescents with cerebral palsy}

The care provided to children and adolescents is continuous, requiring the caregivers to constantly be organized and guarantee the assistance or the necessary material. We went to the Judicial Court and talked to the judge, we went there and wrote a letter and I said that I wanted 300 diapers (FI). I'm trying to get her attended, I'm even trying to get a van, there's no way I can go. Either he does not have the transportation, or he does not have a space, or the person who will attend doesn't show that he wants to do things with her (FIII).

In another statement: we need to change the catheter there, we have to keep on calling. Then I called the SAD [Home Care Service] and the girl said that she couldn't come to our home, she told us to go to the clinic that they have to change it in the clinic. They only want to change it in the clinic, because they say that they do not know how to change her catheter. She uses gastro. Now it's bleeding, because it's been three months and they do not want to change and it needs to be changed, and there's nobody to change it (FXIII).

They highlight the absence of an organized and structured health care network for this specific public, either in specialized services or in basic health units. I believe that if they had a little more commitment, had some program more assigned to families that have children with some kind of disability, I think the access would be a little easier. But they do not have programs that do this, they are not interested in the cause, so unfortunately they have nothing to say (FVII). I think there should have a person, a team, just for this, because not all the teams, not all the people who work there, understand that she has a problem, so they won't know how to deal with her or with her mother, I think, in my opinion, that there should have a team that understands the subject, that studies this subject to deal with the child and with the mother also (FIX).

The participants demonstrate the limits of health services. I asked if they could do a bandage on the child because he was bleeding badly, he is deficient, and they said no, we can't do anything here. And they turned away. As simple as that (FXI). I think they should go deeper into the problem, the difficulty, because they just look at the top, the basics, and they are there to meet people's needs, they should go deeper, to understand why that happened. Be concerned professionals, welcome the patients a little.. But they imagine that they're going to waste their time, I think they think there's a lot of people to attend to, so they do it in anyway old way... (FXVII).

\section{DISCUSSION}

The results showed that the family of a child with special needs has specifics which make it complex, one of the institutions responsible for the development of new skills for caregivers is still under construction. During the experience of the diagnosis of a chronic disease it is necessary the explanations are understandable, and also providing comfort when they are faced with feelings of guilt, uncertainty, mourning and fear. This first contact is essential for caregivers of children with cerebral palsy in order for them to plan their routines, and to fully understand more the health aspects of this child.

In the gestational period the family organizes for the birth of a healthy baby and the impact of the diagnosis of cerebral palsy triggers stages of mourning, shock, denial, acceptance and adaptation. The existence of a disturbance that affects the individuals at the beginning of life causes the caregivers fear, insecurity and physical exhaustion, and the acceptance and adaptation to the demands of care and the concern with the acceptance of the child by the society are all factors which cause family suffering. ${ }^{1,9}$

Chronic and incapacitating illness, which do not necessarily coincide with birth, alters the preexisting dynamics, affecting the personal, conjugal, professional and social life of families, causing limitations to children and their families. ${ }^{3,9}$

In this study, the way of coping and the elaboration of new life projects by the families of children with cerebral palsy were quite diverse. In some cases, parents and grandparents received the news soon after birth during the stay in the ICU; other families noticed changes in the development of children in the recent months after birth and went in search of medical services. After the denial of serious diagnosis, caregivers looked to aspects of faith and courage, developing mechanisms to attenuate the negative feelings caused by the limitations, such as fear and pessimism. ${ }^{10}$

There is evidence ${ }^{3,11}$ that the complexity of caring for children and adolescents with cerebral palsy generates transformations in the family routine, requiring intense dedication of the family, especially from the mother. Such attribution is understood differently in the paternal prism, perceiving that, despite the feeling of denial and questioning, there is a more accurate planning of the future between them. 
The father's participation in the care of these children is much less talked about than the mother's, but their suffering is no less or nonexistent. It is the result of a cultural conception of society, which presents man as a strong foundation for the family, and it is necessary to hide reactions and feelings.

The process of illness is considered an agent of family imbalance, since the diagnosis of the disease impacts the organization of the routines, requiring a reorganization of the subjects' life model. Faced with a stressor, coping with difficulties and developing problem-solving strategies leads individuals to family congruence. ${ }^{12}$ This ability to transform realities, reorganize goals, experience roles, and prioritize is known as family resilience, an ability to reassess the initial condition, learn to value the child's potential, and learn to deal with the limitations of their children.

The interviewed caregivers demonstrate the desire that the children have a significant change in the prognosis, mainly related to the motor acquisitions, often disregarding the reality of some more serious issues, developing a fantasy whose purpose is the relief of suffering. It is part of the adaptation process to the new relationship with the child, when these parents gradually abandon the fantasies of the idealized child and face the conflicts present in this reality. In this process, the potential for family resilience and social support become important components. ${ }^{13}$

Most of the caregivers investigated refer to the need for extreme dedication to the care of their children with cerebral palsy, requiring the abandonment of their free time and daily activities and in the majority of cases, the abandonment of professional activities. ${ }^{3}$ They also reported the need for psychological support at the time of diagnosis and during the experience with the child which is not offered to them, which they described as a cause for illness.

In the statements which support the first category, the issue of explanation the diagnosis, the relationship with health services and the familycentered care-oriented follow-ups are determinant for the child to be understood by family within the child's reality, a condition that eases despair and anguish for all individuals - both for the family and for the professional - who, for the most part, are not prepared to deal with disability.

The difficulty involved in planning health care for disability issues is also associated with the condition of maintaining a scientific perspective, not valuing the salutogenic aspects presented by the child, reinforcing the maintenance of a model that, because it does not clarify a problem observed by the family, generates moments of anguish, fear and anger that extend over a long period of time, culminating in sickness and frailties for the families of these children.

The word care comprises various meanings, it is related to healing, to the sense of love and friendship. It is a process that is present in all phases of human development, a component of health in human beings, since it includes not only the identification of the disease and its cure, but also the support of conditions of chronicity, preserving the dignity of individuals.

Family life is a privileged place for production and practices related to the health-disease process, constituting itself as an important unit of essential care, an informal action network that interrelates with the official network of health care services. ${ }^{14}$ In this context, the difficulties related to the experience of a chronic condition have repercussions not only on the life of the affected individual, but also on the whole family nucleus, implying changes in life habits which require support.

The complexity of chronic disease care is related to its characteristics. These conditions present multiple causes, which evolve gradually with moments of exacerbation, present throughout the life cycle which are capable of compromising the quality of life of individuals, limiting their functionally or incapacitating them, and may result in gradual health deterioration. Thus, they are conditions that promote organic, psychological and social changes, requiring constant care and adaptation of the child and caregiver. ${ }^{15}$

The care provided by the family is often constituted in situations of vulnerability, requiring great efforts, mobilizing resources, culminating in the moral responsibility of care, whose genesis lies in the family history and in the affectivity existing among the people. ${ }^{16}$ Thus, there are innumerable care provision requirements, especially in view of the existence of a chronic disease that lasts over time and implies emotional, economic and social investments.

Family care centrality is considered as a result of informal solidarity, understood as a unit responsible for directing daily attention to individuals with high dependency during their life cycle, often neglected by the State. ${ }^{16}$

As the child grows, there is an increase in the complexity of daily activities, at which time families experience the pronouncement of difficulties, especially those related to neuropsychomotor development. 
Family care is daily, responding to uninterrupted care such as feeding, locomotion and personal hygiene, which is supported by family ties. ${ }^{16}$ These are activities that occur and are justified by the connection, the need to be together, related to the responsibilities and the values considered natural by the family.

The statements demonstrate the absence / lack of the formal responses of the State to the needs of care to the studied population, a condition that contributed in this care becoming a family responsibility.

The analysis of the interviews of the second category allows us to identify the process of care in a prism in which each family discovers the best way to interact with their child, understanding their needs. However, the physical and emotional exhaustion related to the daily life of these individuals in the in the mothers and grandmothers can be observed.

In this study it was observed that the daily life of these individuals is overcome by financial difficulties, multiple activities, feelings of loss of control of one's life, feelings of exclusion and work overload. These feelings are minimized and managed by the help received from the family itself.

In this perspective, the health concerns of children and adolescents with cerebral palsy should not be based solely on the quality of life of these individuals. It is necessary to develop care proposals that consider families, understanding their ways of being and seeing individualized ways of offering care and assistance.

The existence of a chronic disease significantly modifies family routines, ${ }^{3}$ since it demands prolonged and continuous care, which is a major challenge for health systems around the world. Thus, it is necessary to transform a care model centered on the disease to one in which the subject will occupy the condition of centrality, requiring the integration of articulated attention networks ${ }^{4}$ which share the responsibility of the provision of care longitudinality.

Considering the increase in life expectancy for individuals with cerebral palsy and the different ways in which the severity of the condition and the comorbidities affect both the child and family, there is a progressive demand for increasingly complex care during the adolescence and adult life of these subjects. ${ }^{17}$

The confrontation of this condition and the search for care in the health services can be identified in the creation of networks, created by the families of these children aiming for support, going beyond the limits of the formal attention networks and reaching other dimensions, such as legal. Such a search is the attempt to obtain what is neglected to meet the needs of children and adolescents with cerebral palsy.

Thus, it is observed that care for the person with chronic conditions requires the organization of a network of attention, ${ }^{4}$ articulated with actions aimed at the needs not only of the sick person, but also of their family. ${ }^{18}$ With the birth/sickness of the child, the family begins a process of self-care, requiring expanded care and seeking care in primary, secondary and tertiary institutions, in order to guarantee the resources they need.

In the third category regarding the trajectory of search for care, it was found that family care has been neglected by all levels of health care, evidenced mainly in primary health care services, demonstrating that there is no adequate follow-up of this population.

The analysis of the statement allows the inference of the importance of the link between the professionals and the families of these children, ensuring longitudinal care and co-responsibility in the care. ${ }^{19-20}$ In this perspective, the referral to another level of care is configured as the search for the resolution and not the transfer of the individual to another service, denying the participation in the other actions offered. However, this commitment is broken in practice, compromising care management and disrespecting the right to integrity.

The necessary longitudinality of care was not guaranteed to this population during the trajectories of these families. The effectiveness of this long-term relationship could contribute to the independent attention of health problems, proposing the link as an instrument of care for the reach of this relationship. ${ }^{18}$

Three dimensions related to the longitudinal link between patients and health services can be identified: ${ }^{18}$ the regular source of care in primary care dimension (recognition of basic health units as a reference for meeting the population's health needs); Interpersonal dimension relationship (based on the long-term bond, involving trust); And information continuity dimension (related to the quality of health records). These dimensions ensure compliance with this attribute in order to produce more accurate diagnosis and treatment, reducing unnecessary referrals and ensuring complete access to network services.

Barriers to access to specialized outpatient and hospital services, waiting lines, lack of referral / counter-referral between departments, inefficient 
management of resources, hospital readmissions, high average hospital stay rates, and inadequate emergency services, the absence of a sense of continuity of care and the lack of a coordinating service of care are examples of failures in the care networks. ${ }^{21}$

Thus, there is a myriad of actions to be carried out in order to provide adequate care for the families of children and adolescents with chronic diseases.

Regarding limitations for this study, it should be highlighted that the families were treated in a referenced nongovernmental organization in the suburbs of the State of São Paulo, and therefore can be considered as a regional reality. However, it is believed that the results of the study contribute to the improvement of the quality of care for children and adolescents with cerebral palsy because they offer supporg to managers, health workers and SUS users in the search for longitudinal and integral care.

\section{CONCLUSION}

The interviews showed that the caregivers face the unfamiliarity of the repercussions of cerebral palsy and are ill informed by the health professionals regarding the required care imposed by the disease. The inexistence of an articulated network of care to this population was also verified. By describing their journeys in the health services, the caregivers explicitly explained the unfamiliarity regarding actions in the primary care services, some of them remaining nonexistent in the course of care of these individuals. This fragmentation between the different services is a characteristic of our health system, a condition that causes the disoriented wandering of the parents of these children and adolescents in the diverse service providers.

The incoherence between the health situation of children with cerebral palsy and the hegemonic health care system in our country is a problem which needs to be overcome and which requires the involvement and implementation of health care networks. The statements showed the inexistence of this interdependent relationship between the services, impacting on the offer of continuous and integral care coordinated by the PHC.

The lack of articulation between the services that serve the studied population implies discontinuity of attention at the primary, secondary and tertiary levels, deteriorating the quality of care, the quality of life of the children and their families and negatively impacting the sanitary outcomes of the health care system due to the inefficient use of resources and equity in health.
Thus, when the onset of a neurological condition affects a large number of newborns in the same period, we hope that this study demonstrates the importance of establishing adequate flow of care, in which the weaving of the attention networks should not be the responsibility of caregivers, but part of the concern of health service managers in order to guarantee access to health for all.

\section{REFERENCES}

1. Almeida KBB, Araújo LFS, Bellato R. Family caregiving in chronic illness: a young person's experience. Reme: Rev Min Enferm [Internet]. 2014 [cited 2016 Jan 22]; 18(3):724-32. Available from: http:/ / dx.doi.org/10.5935/1415-2762.20140053

2. Tronnes H, Wilcox AJ, Lie RT, Markestad T, Moster D. Risk of cerebral palsy in relation to pregnancy disorders and preterm birth: a national cohort study. Developmental medicine and child neurology. 2014; 56(8):779-85.

3. Baltor MRR, Dupas G. Experiences from families of children with cerebral paralysis in context of social vulnerability. Rev Latino-Am Enfermagem [Internet]. 2013 [cited 2016 Fev 02]; 21(4):956-63. Available from: http://dx.doi.org/10.1590/S0104-11692013000400018

4. Mendes EV. A construção social da Atenção Primária à Saúde, Brasília. Conselho Nacional de Secretários de Saúde (CONASS); 2015.

5. Alves GG, Aerts D. Health education practices and Family Health Strategy. Ciênc Saúde Coletiva. 2011; 16 (1):319-25.

6. Starfield B. Atenção primária: equilíbrio entre necessidades de saúde, serviços e tecnologia. Brasília (DF): Unesco, Ministério da Saúde; 2002.

7. Pedroso MLR, Motta MGC. Children and family living with chronic conditions: mesosystem in connection with program vulnerability. Texto Contexto Enferm [Internet]. 2013 Abr-Jun [cited 2016 Jan 22]; 22(2):4939. Available from: http://www.scielo.br/scielo. php?pid=S0104-07072013000200027\&script $=$ sci arttext\&tlng=en

8. Minayo MCS. O desafio do conhecimento: pesquisa qualitativa em saúde. 12a ed. São Paulo(SP): Hucitec; 2015.

9. Gondim KM, Carvalho ZMF. Sentimentos das mães de crianças com paralisia cerebral à luz da teoria de Mishel. Esc Anna Nery. 2012 Jan-Mar; 16(1):11-6.

10. Chacon MCM. Aspectos relacionais, familiares e sociais da relação pai-filho com deficiência física. Rev Bras de Educ Esp [Internet]. 2011 [cited 2016 Jan 22]; 17(3):441-58. Available from: http://dx.doi. org/10.1590/S1413-65382011000300007

11. Dezoti AP, Alexandre AMC, Freire MHS, Mercês NNA, Mazza VA. Social support to the families of children with cerebral palsy. Acta Paul Enferm. 2015; 28(2):172-6. 
12. Peixoto MJ, Martins T. Adaptação do perfil de resiliência familiar à população portuguesa. Psic., Saúde e Doenças [Internet]. 2012 [cited 2016 Jan 22]; 13 (2):372-88. Available from: http:// www.scielo.mec.pt/scielo.php? script $=$ sci $_{-}$ arttext\&pid=S1645-00862012000200017

13. Pedroso CNLS, Félix MA. Percepção dos pais diante do diagnóstico e da abordagem fisioterapêutica de crianças com paralisia cerebral. Rev Ciênc e Saúde. 2014 Mai-Ago; 7(2):61-70.

14. Queiroz TA, Carvalho FPB, Simpson CA, Barreto ELF, Fernandes ACL. Família: significado para os profissionais da Estratégia de Saúde da Família. Rev Bras Promoç Saúde. 2015 Abr-Jun; 28(2):274-80.

15. Sclindwein-Zanini R, Almeida G. O estigma em crianças com doenças crônicas: uma questão de Saúde Pública. Fiep Bulletin [Internet]. 2012 [cited 2016 Jan 22]; 82(1). Available from: http:// fiepbulletin.net/ index.php/fiepbulletin/article/view/2502/4606

16. Alves JMPM. Vidas de Cuidado(s): uma análise sociológica do papel dos cuidadores informais [tese]. Coimbra (PT): Faculdade de Economia da Universidade de Coimbra; 2011.
17. Simões CC, Silva L, Santos MR, Misko MD, Bousso RS. A experiência dos pais no cuidado dos filhos com paralisia cerebral. Rev Eletr Enferm [Internet]. 2013 [cited 2016 Jan 22]; 15(1):138-45. Available from: https://www.fen.ufg.br/fen_revista/v15/n1/pdf/ v15n1a16.pdf

18. Cunha EM, Giovanella L. Longitudinality/continuity of care: identifying dimensions and variables to the evaluation of Primary Health Care in the context of the Brazilian public health system. Ciênc Saúde Coletiva. 2011; 16(1):S1029-42.

19. Araújo RL, Mendonça AVM, Sousa MF. Percepção dos usuários e profissionais de saúde no Distrito Federal: os atributos da atenção primária. Saúde Debate. 2015; 39(105):387-99.

20. Frank BRB, Viera CS, Ross C, Obregón PL, Toso BRGO. Avaliação da longitudinalidade em unidades de Atenção Primária à Saúde. Saúde Debate. 2015; 39(105):400-10.

21. Vargas I, Vázquez ML, Mogollón-Pérez AS, Unger JP. Barriers of access to care in a managed competition model: lessons from Colombia. Social Sci e Med. 2014 Abr; 106:204. 